\title{
The "New" Federal Judicial Appointments Process: The First Ten Years
}

\author{
ANDRE S. MILLAR
}

This article provides a brief history of the process for selecting federally appointed judges, which was first announced in 1988. The article summarizes the major changes in the selection process since 1988 and provides descriptions of some of the key policies and procedures. Several Appendices present further information on the selection process for the years 1989 to 1999. The Appendices include a statistical report of applications, recommendations and appointments, the members of the Advisory Committees, the Ministers of Justice and Commissioners for Federal Judicial Affairs, and the Personal History Form for candidates for judicial selection. Please note that events and information after December. 1999, are not reflected in the above material.
Cet article donne un bref historique du processus de sélection des juges nommés aux tribunaux fédéraux, processus qui a été annoncé pour la première fois en 1988. L'article résume les grands changements du processus de sélection depuis 1988 et décrit certaines des politiques et méthodes clés. Plusieurs annexes donnent plus d'information sur le processus de sélection en place de 1989 à 1999. Les annexes incluent un rapport statistique sur les applications, les recommandations et les nominations, les membres des comités consultatifs, les ministres de Justice et commissaires de la magistrature fédérale ainsi que les formulaires des antécédents personnels des candidats. Veuillez noter que les événements et l'information après décembre 1999 ne figurent pas dans le matériel susmentionné.

\section{Table of Contents}

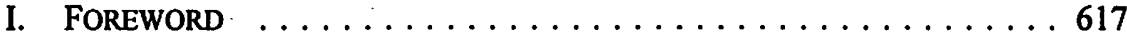

II. HISTORY OF THE FEDERAL JUDICIAL APPOINTMENTS

PROCESS 1998-1999 . . . . . . . . . . . . . . . . . . . 617

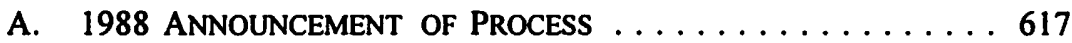

B. Subsequent Changes to the Process . . . . . . . . . 619

C. CHRONOLOGY OF ADVISORY COMMITTEES

$1988-1999 \ldots \ldots \ldots \ldots \ldots \ldots \ldots \ldots \ldots \ldots . \ldots 620$

III. AdDITIONAL NOTES ON PROCESS, POLICIES,

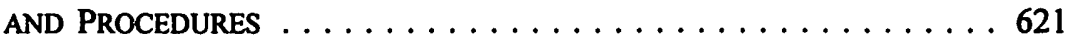

A. CoMmittee MEMBERS AND PROCEDURES $\ldots \ldots \ldots \ldots 621$

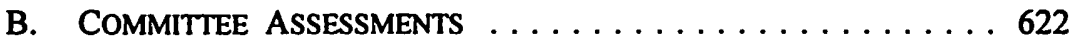

C. LAW Society CleARANCES $\ldots \ldots \ldots \ldots \ldots \ldots \ldots \ldots 622$

D. PERSONAL History ForM $\ldots \ldots \ldots \ldots \ldots \ldots \ldots \ldots 622$

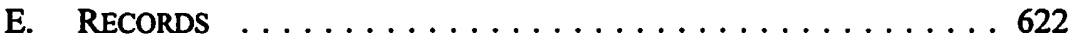

Judicial Appointments Secretary, Office of the Commissioner for Federal Judicial Affairs, Ottawa. Any errors in this recounting are mine. No record of the appointments process would be complete without an expression of gratitude to the several hundred Committee members in all parts of Canada, and from all walks of life, who have been the heart of this process and whom I have had the privilege to work with and to learn from. 1 am also indebted to all the Law Societies in Canada and the Ontario LPIC who have assisted me by providing timely information on candidates for the Bench. My thanks also extend to the Commissioner for Federal Judicial Affairs, Mr. Guy Goulard, and to my two assistants Anne-Marie Mongrain and Louise Renaud, for the support they provide $m e$ in the daily management of the appointments process. These notes are in memory of my father, James A. Millar, Q.C. 


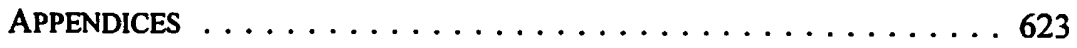

1. JUDICIAL APPOINTMENTS PROCESS -

Cumulative Statistics $1989-1999 \ldots \ldots \ldots \ldots$. . . . . . 623

2. JUDICIAL APPOINTMENTS PROCESS - ADVISORY

COMMITTEe MEMBERS 1989-1999 ..............6 624

3. MINISTERS OF JUSTICE AND COMMISSIONERS FOR

FEDERAL JUdicial AFFAIRS $1988-1999 \ldots \ldots \ldots \ldots \ldots 633$

4. PERSOnAl History Form $\ldots \ldots \ldots \ldots \ldots \ldots \ldots \ldots 634$

5. CANDIDATES FOR FEDERAL JUDICIAL APPOINTMENT - CRITERIA $\ldots \ldots \ldots \ldots \ldots \ldots 647$

\section{FOREWORD}

The current federal judicial appointments process was announced by the Minister of Justice in 1988, and fully implemented in 1989 when the Advisory Committees created under the process became operational. As of the end of 1999, more than 5000 applications for the Bench had been received, well over 400 Advisory Committee meetings held to assess these applicants in every province and territory of Canada, and close to 600 applicants appointed to a provincial superior court, the Federal Court of Canada, or the Tax Court of Canada. The author has been responsible to the Commissioner for Federal Judicial Affairs for the day-to-day management of this process, and a witness to its development during those first ten years. These notes are intended as a brief record of those years for those who are not familiar with the process; they should not be taken as a comment on, or an analysis of, the regime.

\section{HISTORY OF THE FEDERAL JUdiCIAL APPOINTMENTS ProCesS 1988-1999}

\section{A. 1988 announcement of Process}

A new process for selecting federally appointed judges was announced by the federal Minister of Justice, the Honourable Ray Hnatyshyn, during an address to the Law Day Dinner in April 1988.' It was the result of a review of the judicial appointments process, requested earlier by the Prime Minister, which had brought about consultations with a wide array of interested groups and individuals, including a review of previous recommendations made by the Canadian Bar Association.

The highlights of the new appointments process were stated as follows in the Minister's accompanying press release:

Highlights of New Judicial Appointments Process

The new process is designed to enable all interested and qualified individuals to be considered for appointment, and to provide a means by which the Minister of Justice can receive broadlybased and objective advice about their qualification for appointment.

I R. Hnatyshyn, Address (Law Day Dinner, Ottawa, 14 April 1988) [unpublished]. 
- A committee will be set up in each province and territory. Membership will consist of one nominee each from the provincial or territorial branch of the Canadian Bar Association, the provincial or territorial Law Society, the Chief Justice for that jurisdiction, the Attorney General or Minister of Justice of the province or territory, and the federal Minister of Justice, who will choose, as his nominee, a person capable of representing the broader community interest.

The process will be administered by the Commissioner for Federal Judicial Affairs.

The Commissioner will in turn refer the names to the appropriate committee for consideration, after determining that they meet the necessary technical qualifications. The Commissioner will also provide secretariat services to each committee.

- Committees will meet frequently, as required, and in any event, no less than twice a year.

- After considering the qualifications of individual candidates, committees will advise the Minister of Justice whether each is qualified or not qualified for appointment.

- Where a committee advises that an individual is qualified for appointment, that advice will be valid for a period of two years (i.e., that person may be appointed at any time within the twoyear period without further reference to the committee concerned. This is the practice currently followed by the Canadian Bar Association's Judicial Appointment Committee).

- If a committee advises that a candidate is not qualified, it will be required to give reasons for that conclusion. In the interests of faimess, the individual concerned will have an opportunity to review and comment on these reasons, if he or she so wishes.

- In addition to receiving the advice of the committees, the Minister will continue to consult provincial and territorial Ministers and Chief Justices directly about appointments within the province or territory concerned.

- After the advice of the appropriate provincial committee has been received, and other consultations have been carried out, the government will make the final decision on an appointment.

- The new process will extend to initial appointments to the Bench, except it will not apply to appointments to the Supreme Court of Canada. The Meech Lake Accord will empower the provinces to propose qualified candidates to fill vacancies on the Supreme Court, while the Federal Government will retain its prerogative to make the appointments.

- The process of implementing the new process will begin immediately, with a view to having it fully operational within the next few months. The Canadian Bar Association's Judicial Appointment Committee has agreed to continue to advise the government in the meantime. ${ }^{2}$

The document "Highlights of New Judicial Appointments Process" was attached to the following press release; Minister of Justice and Attomey General of Canada, News Release, "New Process for Selecting Federally-Appointed Judges Announced" (14 April 1988). 
The companion booklet "A New Judicial Appointments Process"3 published in 1988 added that the concept of merit would be central, and that broad consultations and community involvement were essential elements. It noted as features of the revised system the establishment of independent committees for the assessment of candidates, the conferral of the bulk of the recruitment functions upon an individual independent of the office of the Minister of Justice, and the continued consultation with provincial attorneys general, territorial justice ministers, and the chief justices.

In a September 1988 letter to Mr. Pierre Garceau, the then Commissioner for Federal Judicial Affairs, the Minister of Justice outlined the Commissioner's responsibilities under the new process which were being conferred pursuant to a provision of the Judges Act. ${ }^{4}$ It would be the Commissioner's responsibility to solicit applications and maintain records of all those interested in appointment to a federal judicial position, to refer these names to the appropriate provincial or territorial Advisory Committee for assessment, and to report these assessments to the Minister so that appointments could be made by the Minister from this list on an ongoing basis.

The Commissioner is expected to ensure that the system treats all candidates for judicial office fairly and equally. The Judicial Appointments Secretary acts as his delegate in the administration of the process.

The first "Advisory Committees on Judicial Appointments" were appointed by the Minister of Justice in October 1988, but did not commence operations until 1989. A Committee was appointed for each of the ten provinces and two territories. (In February 1999, a Committee was also appointed for the new territory of Nunavut).

\section{B. Subsequent Changes to the Process}

Changes in process, policy, or procedures were made by the Minister of Justice in 1991, 1994, and 1999 - all of these the result of ongoing operational experience.

In 1991, it was decided that the two "Qualified"/"Not Qualified" designations for Committee assessments would be replaced by the following three designations: "Highly Recommended," "Recommended," or "Unable to Recommend" for appointment. It was felt that these categories would better reflect the advisory nature of the Committee process, as well as allow Committees to give additional weight to those candidates they felt were outstanding. Committees were also asked to provide the Minister with a précis of the candidate's qualities which lead to the assessment. Assessments would henceforth be valid for three years, and would be provided to the Minister only. Committee members would be re-appointable for a single additional term.

In 1994, following extensive consultations, the Minister introduced a number of additional changes. The single Committee for Ontario was replaced by three regional

3 Canada, Department of Justice, A New Judicial Appointments Process (Ottawa: Minister of Supply and Services, Canada, 1988).

4 Judges $A c t$, R.S.C. 1985 , c. J-1, s. 73. 
committees - one each for East and North Ontario, West and South Ontario, and Metro Toronto. Similarly, the single Quebec Committee was replaced by two committees - one for Quebec West and one for Quebec East in accordance with the Quebec judicial districts reporting to the Montreal or Quebec divisions of the Quebec Court of Appeal. All provincial and territorial Committees also received two additional members, increasing the representation of non-lawyers and resulting in a total of seven members for each Committee. Lawyer Committee members were barred from being candidates themselves until a full year after the expiry of their Committee term. The Personal History Form (see Appendix 4) for candidates was expanded substantially to provide more comprehensive information to the assessing Committee and the Minister. As well, Allan Rock, the then Minister of Justice, stated his personal undertaking not to recommend to Cabinet any person not previously recommended by a Committee; although no lawyers had until then been appointed without this recommendation, his undertaking confirmed a practice which has continued to this day.

In 1999, the term of office for Committee members was extended from two to three years. The period during which Committee assessments are valid was reduced from three to two years. The Minister also provided that provincial or territorial court judges - who until now had been placed on the list of those available for appointment without Committee review - would henceforth be the subject of non-binding comments by the appropriate Committee. An annual meeting of the Minister with the Chairs of all Committees was also implemented, formalizing what was already developing as a practice.

\section{Chronology of Advisory Committees 1988-1999}

Advisory Committees have been appointed - or extended - by the Minister of Justice as follows (Nunavut excepted save where noted):

\begin{tabular}{|c|c|c|c|}
\hline $\begin{array}{l}\text { Appointed } \\
\text { Expired }\end{array}$ & $\begin{array}{ll}\text { - } & \text { Oct. } 1988 \\
\text { - } & 30 \text { Sept. } 1990\end{array}$ & - & $\begin{array}{l}\text { All Committees } \\
\text { All Committees }\end{array}$ \\
\hline Appointed & 1991 & - & All Committe \\
\hline Expired & 30 June 1993 & - & All Committees \\
\hline Appointed & Sept. 1993 & - & SASK/BC/A \\
\hline Expired & 31 Dec 1993 & - & SASK/BC/AB \\
\hline Appointed & 1994 & - & All Committees \\
\hline Expired & - $\quad 30$ June 1996 & - & All Committees \\
\hline Extended & - July 1996 & - & All Committees \\
\hline Expired & - $\quad 31$ Oct. 1996 & - & All Committe \\
\hline Appointed & 1997 & - & All Committe \\
\hline Expired & 31 Dec. 1998 & - & All Committe \\
\hline Extended & - $\quad$ Jan. 1999 & - & All Committees \\
\hline Expired & - 31 May 1999 & - & All Committe \\
\hline
\end{tabular}




$\begin{array}{lllll}\text { Appointed } & - & \text { Feb. } 1999 & - & \text { Nunavut Committee (NU) } \\ \text { To expire } & - & 31 \text { May 2001 } & - & \text { Nunavut Committee (NU) } \\ & & & & \\ \text { Appointed } & - & 1999 \text { and } 2000 & - & \text { All Committees } \\ \text { To expire } & - & 30 \text { June } 2002 & - & \text { All Committees }\end{array}$

See Appendix 2 for a list of persons who have served on the above Committees (to 31 December 1999), and Appendix 1 for a statistical overview of the work of the Committees.

\section{Additional Notes on Process, Policies, ANd Procedures}

\section{A. Committee Members and Procedures}

All seven Committee members are appointed by the federal Minister of Justice, four of them after an invitation for names from the appropriate provincial or territorial Chief Justice, Attorney General/Minister of Justice, Law Society and CBA Branch. In appointing persons to serve on each Committee, the Minister attempts to reflect a balance of factors appropriate to the jurisdiction including geography, language, and multiculturalism, in addition to gender. Committee members serve long hours in the consultations and preparations required for each meeting, and in attending the meetings. All of this work is performed pro bono. Three of the seven members on each Committee have been non-lawyers as representatives of the community at large.

Committees normally meet six to eight times a year in the larger provinces, one to four times elsewhere. The Committee Chairs meet in Ottawa with the Minister annually to exchange views on Committee operations, and to suggest changes helpful to the process.

Separate information and orientation sessions are held with each new Committee following its appointment by the Minister.

Each Committee elects its own Chair and any Committee member is eligible. The Chair is responsible for ensuring that all required consultations and investigations in respect of each candidate are carried out. These can be extensive, and are undertaken in both the legal and the non-legal community.

Committee decisions regarding each candidate are normally arrived at through a consensus without recourse to a vote. Where consensus is not possible, a vote is taken. All Committee consultations and proceedings take place on a confidential basis.

Four members constitute a Committee quorum, although most meetings are attended by all seven members. Members can also participate by telephone conference where they would otherwise be unable to attend. 
The Judicial Appointments Secretary, or the Commissioner for Federal Judicial Affairs, must attend each Committee meeting to record and certify Committee decisions prior to their submission to the Minister.

\section{B. COMmittee ASSESSMentS}

Professional competence and overall merit are the primary qualifications, and Committee members are provided with specific criteria to assess these. See Appendix 5 for a list of the criteria.

Committee decisions fall into one of three categories: "Highly Recommended," "Recommended," or "Unable to Recommend" for a judicial appointment. Candidates are informed of the date of their assessment but not of the Committee decision. After the expiry of the assessment, currently after two years, the candidate may re-apply if not appointed.

\section{LaW Society Clearances}

Before submitting a candidate's file to the Committee, the Judicial Appointments Secretary must obtain a confirmation from the appropriate Law Society certifying the candidate's good standing at the Bar. The Law Society is also asked to provide information concerning any pending charges or past convictions for professional or other misconduct, and any information that could affect the candidate's fitness for appointment. This information is transmitted to the Committee together with the candidate's file.

\section{Personal History Form}

This is the application form completed by each candidate and submitted to the Advisory Committee. The form is mandatory for each candidate, in addition to any other documentation the candidate wishes to submit. The Personal History Form is designed to provide comprehensive data for review by the Committee. Appendix 4 reproduces the current edition (December, 1999) of this form, as well as general information supplied to candidates.

\section{E. RECORDS}

Records of Committee proceedings and the candidates' files form part of separate, confidential archives in the Commissioner's office, divorced from, and not accessible by, the other operations of that office. They are also exempt from the operation of access to information legislation. These records are automatically destroyed after four years. 


\section{APPENDIX 1}

\section{Judicial APPOINTMENTS PROCESS 1989-1999 Statistical RePORT}

\begin{tabular}{|l|c|c|c|c|c|}
\hline & $\begin{array}{c}\text { Applications } \\
\text { Received }\end{array}$ & $\begin{array}{c}\text { Recommended } \\
\text { \& Highly } \\
\text { Recommended }\end{array}$ & $\begin{array}{c}\text { Unable to } \\
\text { Recommend }\end{array}$ & $\begin{array}{c}\text { Candidates } \\
\text { Appointed }\end{array}$ & $\begin{array}{c}\text { Committee } \\
\text { Meetings }\end{array}$ \\
\hline Alberta & 444 & 165 & 227 & 61 & 46 \\
\hline B.C. & 487 & 126 & 303 & 74 & 39 \\
\hline Manitoba & 214 & 104 & 77 & 27 & 29 \\
\hline $\begin{array}{l}\text { New } \\
\text { Brunswick }\end{array}$ & 179 & 87 & 69 & 14 & 19 \\
\hline Newfoundland & 112 & 56 & 32 & 14 & 16 \\
\hline Nova Scotia & 265 & 93 & 120 & 33 & 27 \\
\hline Ontario & 1865 & 736 & 867 & 209 & 120 \\
\hline P.E.I. & 48 & 27 & 17 & 6 & 10 \\
\hline Québec & 1175 & 399 & 668 & 124 & 85 \\
\hline Saskatchewan & 188 & 89 & 75 & 28 & 25 \\
\hline Territories (3) & 56 & 10 & 22 & 5 & 21 \\
\hline Total - Canada & 5033 & 1892 & 2477 & 595 & 437 \\
\hline
\end{tabular}




\section{APPENDIX 2}

\section{JUdicial APPOINTMENTS Process AdVISORY COMMITTEE MEMBERS 1989-1999}

NAME

\section{Alberta}

Amonson, Johanne L.

Bishop, D.G.

Boyes, Judy N.

Calliou, George

Cavanaugh, Catherine

Conrad, Carole

Felesky, Brian

Gagnon, Yolande

Grantham, Ron

Hetherington, Mary M.

Joshee, Krishan, C.

Khullar, Ritu

Lebo, James

Martin, Peter W.L.

Martland, John G.

McMahon, Terrence $F$.

Newman, Pat

Nielsen, Kenneth

Reimer, Jan

Ross, Sheilagh

Ruston, Rhonda

Sinclair, William

Singhmar, Prem P.

Smith, Phyllis A.

Snedden, John

Sterk, John

Stollery, Douglas

Strain, Terry

Veit, Joanne

Wittmann, Neil C.

\section{British Columbia}

Beckerman, Jerrold

Branson, Cecil O.D.

Brown, Mary

Brown, Trudi

\section{REPRESENTING}

Canadian Bar Association

Provincial Law Society

Canadian Bar Association

Minister of Justice (Federal)

Minister Of Justice (Federal)

Chief Justice

Canadian Bar Association

Minister of Justice (Federal)

Minister of Justice (Provincial)

Chief Justice

Minister of Justice (Provincial)

Minister of Justice (Federal)

Canadian Bar Association

Provincial Law Society

Provincial Law Society

Provincial Law Society

Minister of Justice (Federal)

Provincial Law Society

Minister of Justice (Federal)

Minister of Justice (Provincial)

Minister of Justice (Federal)

Chief Justice

Minister of Justice (Provincial)

Provincial Law Society

Minister of Justice (Provincial)

Canadian Bar Association

Canadian Bar Association

Minister of Justice (Federal)

Chief Justice

Provincial Law Society
Minister of Justice (Federal)

Provincial Law Society

Minister of Justice (Federal)

Canadian Bar Association 
Dohm, Patrick

Doman, Harbanse

Donald, Ian

Doust, Leonard

Dutt, Shyla

Esson, William

Hall, John

Jackson, Judy

Kan, Angela

Laird, Allan D.

Leask, Peter

Lytle, Linda

McGraw, Robert

McInnes, D.L. David

Murray, Pamela

Nathanson, Irwin

Neilson, Kathryn E.

Peck, Richard C.

Rae, Barbara

Ryan, Vivian

Salley, Louis P.

Silversides, Donald A.

Sugden, Richard

Talmey, Lauris

Whittington, Barbara A.
Chief Justice

Minister of Justice (Provincial)

Chief Justice

Provincial Law Society

Minister of Justice (Provincial)

Chief Justice

Chief Justice

Minister of Justice (Federal)

Minister of Justice (Provincial)

Minister of Justice (Provincial)

Provincial Law Society

Minister of Justice (Provincial)

Minister of Justice (Federal)

Minister of Justice (Federal)

Provincial Law Society

Canadian Bar Association

Provincial Law Society

Provincial Law Society

Minister of Justice (Federal)

Minister of Justice (Federal)

Minister of Justice (Federal)

Minister of Justice (Federal)

Canadian Bar Association

Minister of Justice (Federal)

Minister of Justice (Federal)

\title{
Manitoba
}

\author{
Bedford, Douglas \\ Brown, Mona \\ Chaput, Maria \\ Dangerfield, C. Kristin \\ Dixon, Graham \\ Duval, Léa \\ James, June \\ Jewers, Gerald \\ Jones, Rees $\mathbf{M}$. \\ Konzelman, Ruth \\ Ledohowski, Leo \\ Lister, Eric G. \\ MacInnes, A.D. \\ MacInnes Alan \\ Mauro, Arthur \\ McJannet, Jack \\ Monnin, Michel \\ Provincial Law Society \\ Minister of Justice (Federal) \\ Minister of Justice (Federal) \\ Canadian Bar Association \\ Minister of Justice (Federal) \\ Chief Justice \\ Minister of Justice (Federal) \\ Chief Justice \\ Minister of Justice (Provincial) \\ Minister of Justice (Federal) \\ Minister of Justice (Provincial) \\ Canadian Bar Association \\ Chief Justice \\ Provincial Law Society \\ Minister of Justice (Provincial) \\ Canadian Bar Association \\ Chief Justice \\ Ogaranko, Andrew D.M. \\ Minister of Justice (Federal)
}


Orle, G.J.

Pollard, Lawrence

Richardson, Tannis

Scurfield, John

Suche, Colleen

Twaddle, A. Kerr

Watson, Gail

\section{New Brunswick}

Auffrey, Lucille

Basque, G. Robert

Creaghan, Paul

Dixon, Ray

Doiron, Peggy

Drapeau, Ernest

Drummie, Thomas B.

Fafard Godbout, Marcelle

Ferlatte, Georgette

Garey, Norman

Gorham, R. Hugh

Gorman, Patrick

Graser, Weldon

Hoyt, William

Larlee, Margaret

Leger, Franklin

Levesque, Jacques

MacPherson, Judith

McKelvey, E. Neil

Sargeant, Charles

Savoie, Dennis A.

Shippee, Douglas

Teed, Eric L.

White, William B.

Williamson, Harry

\section{Newfoundland}

Althouse, D. Paul

Barry, Thomas

Cameron, Margaret

Carpenter, Reginald

Farrell, Jaimie Anne

Greene, Mabel

Gullage, John
Canadian Bar Association

Minister of Justice (Federal)

Minister of Justice (Provincial)

Provincial Law Society

Provincial Law Society

Chief Justice

Minister of Justice (Federal)
Minister of Justice (Federal)

Minister of Justice (Federal)

Chief Justice

Canadian Bar Association

Minister of Justice (Federal)

Chief Justice

Minister of Justice (Federal)

Minister of Justice (Federal)

Minister of Justice (Provincial)

Minister of Justice (Provincial)

Minister of Justice (Federal)

Provincial Law Society

Chief Justice

Chief Justice

Chief Justice

Canadian Bar Association

Minister of Justice (Federal)

Canadian Bar Association

Provincial Law Society

Provincial Law Society

Minister of Justice (Provincial)

Minister of Justice (Federal)

Canadian Bar Association

Provincial Law Society

Canadian Bar Association
Canadian Bar Association

Minister of Justice (Federal)

Chief Justice

Minister of Justice (Federal)

Minister of Justice (Federal)

Minister of Justice (Provincial)

Minister of Justice (Federal) 
Gushue, James

Henley Andrews, Janet M.

Hurley, David

Kelsey, Patricia

MacNab, R.A. Gordon

Noseworthy, Ronald

Pittman, Robert P.

Poole, Edward P.

Richard, Agnes

Roil, John F.

Rose, Linda

Steele, Geoffrey

Strong, Peter

Warren, Phillip

Whalen, Norman J.

\section{Nova Scotia}

Barker, John

Bateman, Nancy

Burchell, Thomas J.

Caldwell, Patricia

Chiasson, George

Cluney, Reginald

Davison, John

Johnston, Brian G.

Jones-Darrell, Janis

LeBlanc, Charles

Lewis, Daurene E.

Lewis, Harvey

Lloy, Sharon

Lord, Carol

MacAdam, A. David

MacDonald, Robert

MacKinnon, Kenzie

Macleod, Malcolm

Nee, Michael

Owen, G. Michael

Rafferty, John T.

Stewart, David A.

Unsworth, Sharon M.

Wade, William F.S.

Walker, N. Barbara

Wrathall, Harry
Chief Justice

Provincial Law Society

Canadian Bar Association

Minister of Justice (Provincial)

Canadian Bar Association

Minister of Justice (Federal)

Canadian Bar Association

Provincial Law Society

Minister of Justice (Federal)

Provincial Law Society

Provincial Law Society

Chief Justice

Provincial Law Society

Minister of Justice (Provincial)

Minister of Justice (Federal)

Provincial Law Society

Chief Justice

Provincial Law Society

Provincial Law Society

Minister of Justice (Federal)

Canadian Bar Association

Chief Justice

Canadian Bar Association

Minister of Justice (Provincial)

Minister of Justice (Federal)

Minister of Justice (Provincial)

Minister of Justice (Federal)

Minister of Justice (Federal)

Minister of Justice (Federal)

Chief Justice

Chief Justice

Minister of Justice (Federal)

Canadian Bar Association

Minister of Justice (Provincial)

Minister of Justice (Federal)

Canadian Bar Association

Provincial Law Society

Minister of Justice (Federal)

Minister of Justice (Provincial)

Minister of Justice (Federal)

Provincial Law Society 
Allen, Bertha

Bengts, Elaine $\mathrm{K}$.

Brockman, Aggie

Bromley, Barbara

Cooper, Donald

de Weerdt, Mark

Dolphus, Georgina

Foldats, Valdis

Hanson, Dale Christine

Hardy, Richard

Heron-Hebert, Suzanne

Lamalice, Shirley

Lantz, Angie

MacDonald, David

Peterson, Katherine R.

Phillips, Gerard K.

Richard, J.E.

Schuler, Virginia

Schuler, Virginia A.

Stewart, Elizabeth

Vertes, John

Whitford, Anthony

Williams, Jack

\section{Nunavut}

Bayly, John

Browne, Beverly A.

Cooper, Susan

Dean, Bernadette

Erkloo, Elijah

Keenainak, Simeonie

Malakoe, Garth

\section{Ontario}

Backhouse, Nancy

Bell, J.M.

Byers, David

Campbell, Carolyn

Campbell, Colin

Cauley, Frank J.

Chandler, Marsha
Minister of Justice (Territorial)

Canadian Bar Association

Minister of Justice (Federal)

Minister of Justice (Federal)

Territorial Law Society

Senior Judge

Minister of Justice (Federal)

Canadian Bar Association

Minister of Justice (Federal)

Territorial Law Society

Minister of Justice (Territorial)

Minister of Justice (Territorial)

Minister of Justice (Federal)

Canadian Bar Association

Territorial Law Society

Minister of Justice (Federal)

Senior Judge

Senior Judge

Territorial Law Society

Territorial Law Society

Canadian Bar Association

Minister of Justice (Territorial)

Minister of Justice (Federal)
Canadian Bar Association

Senior Judge

Territorial Law Society

Minister of Justice (Federal)

Minister of Justice (Federal)

Minister of Justice (Territorial)

Minister of Justice (Federal)
Provincial Law Society

Chief Justice

Minister of Justice (Federal)

Minister of Justice (Federal)

Provincial Law Society

Minister of Justice (Provincial)

Minister of Justice (Federal) 
Cressy, Gordon

Curry, J. Thomas

Daigle, Reno

Dotten, Rose

Dowler, George

Dutt, Sheila

Echlin, Randall S.

Evans, John F.

Feinstein, Abraham

Ferrier Lee K.

Finkelstein, Neil

Fuerst, Michelle

Gaskell, Sandra

Goudge, Stephen

Grange, Samuel G.M.

Grant, Stephen

Hansen, Nancy

Henderson, John

Houlden, Lloyd

Lacroix, J. André

Lamarche, Arthur J.M.

Laskin, John

Lloyd, Christine

MacLean, Loraine V.

Matheson, William A.

McCaughey, Andrew

McDougall, Thomas

McGarry, John F.

McGrath, Ted

Métivier, Monique

Michaud, Lucille

Miller, Donna

Mills, Darrell

Monahan, Paul

Morin, Gerald

Murphy, Dan

Murray, Ross

O'Connor, Dennis

Osborne, C.A

Paquette, André

Paquette, Jean-Jacques

Paquette, Ryan M.

Ralph, Warren

Scott, David

Sealy, Hope

Sinclair, MacGregor

Smith, Robert J.
Minister of Justice (Provincial)

Provincial Law Society

Minister of Justice (Federal)

Minister of Justice (Provincial)

Minister of Justice (Federal)

Minister of Justice (Provincial)

Minister of Justice (Federal)

Canadian Bar Association

Provincial Law Society

Chief Justice

Provincial Law Society

Canadian Bar Association

Minister of Justice (Provincial)

Minister of Justice (Federal)

Chief Justice

Canadian Bar Association

Minister of Justice (Provincial)

Canadian Bar Association

Chief Justice

Canadian Bar Association

Minister of Justice (Federal)

Chief Justice

Minister of Justice (Federal)

Minister of Justice (Federal)

Minister of Justice (Federal)

Minister of Justice (Federal)

Minister of Justice (Federal)

Chief Justice

Minister of Justice (Federal)

Chief Justice

Minister of Justice (Federal)

Minister of Justice (Federal)

Minister of Justice (Provincial)

Minister of Justice (Federal)

Chief Justice

Provincial Law Society

Provincial Law Society

Provincial Law Society

Chief Justice

Minister of Justice (Federal)

Canadian Bar Association

Canadian Bar Association

Minister of Justice (Provincial)

Provincial Law Society

Minister of Justice (Federal)

Minister of Justice (Federal)

Canadian Bar Association 
Stewart, Janet

Strosberg, Harvey

Tice, Mary

Weiler, Karen

Williams, Jean Pearl

Young, Sandra

\section{Prince Edward Island}

Anderson, Donald

Campbell, Gordon

Curley, Shauna

DeBlois, Thomas

DesRoches, Armand

Fitzpatrick, Milton

Hubley, Roberta

Large, D.P.

Large, Donald P.

MacKay, J. Gordon

MacKenzie, J. Scott

Maloney, John

Matheson, Jacqueline

McLellan, Bloyce

Michael, Paul D.

Mitchell, Gerard

Mitchell, John

Murphy, Shawn

Orr, Nancy

Reid, Wendy

Roche, Everett

Sanderson, David

Smith, Anne

Stewart, Graham

Toombs, Jayne

\section{Quebec}

Beaudoin, Claude

Bellemare, Daniel

Boulet, Gilles

Boulet, Nicole

Brossard, André

Bélainsky, Marie-Josée

Béliveau, Lionel

Cain, Michael
Minister of Justice (Federal)

Provincial Law Society

Minister of Justice (Federal)

Chief Justice

Minister of Justice (Federal)

Minister of Justice (Provincial)
Minister of Justice (Federal)

Canadian Bar Association

Canadian Bar Association

Minister of Justice (Federal)

Chief Justice

Minister of Justice (Provincial)

Minister of Justice (Federal)

Provincial Law Society

Minister of Justice (Federal)

Provincial Law Society

Canadian Bar Association

Minister of Justice (Provincial)

Chief Justice

Provincial Law Society

Minister of Justice (Federal)

Chief Justice

Canadian Bar Association

Provincial Law Society

Provincial Law Society

Canadian Bar Association

Minister of Justice (Federal)

Minister of Justice (Federal)

Minister of Justice (Federal)

Provincial Law Society

Minister of Justice (Provincial)
Minister of Justice (Federal)

Canadian Bar Association

Minister of Justice (Federal)

Minister of Justice (Provincial)

Chief Justice

Canadian Bar Association

Minister of Justice (Provincial)

Minister of Justice (Federal) 
Caron, Michel

Delisle, Jacques

Deslongchamps, André

Ferland, Denis

Fortin, Lucie

Gagnon-Duperrey, Liliane G.

Garceau, Pierre

Germain, Patricia

Gervais, Michel

Grand Maître, Marcel

Guibault, Jean

Guy, Andrée

Hickson, Michael

Jolin, Michel

Koutchougoura, George

Lagace, Maurice

Lemelin, Jean

Lesage, Robert

Létourneau, Serge

Mongeon, Robert

Normandeau, Monique

O'Rourke, Suzanne

Pateras, Bruno J.

Petras, Eva

Provencher, Jean-François

Rousseau-Houle, Thérèse

Savic, Caroline-Ivana

Setlakwe, Raymond

Setlakwe, Raymond

Synnott, Bernard

Sébastien, Pierre

Tremblay, Joseph A.

Turner, Peter

Vaillancourt, Louis

Vennat, Michel
Provincial Law Society

Chief Justice

Chief Justice

Canadian Bar Association

Minister of Justice (Federal)

Canadian Bar Association

Minister of Justice (Federal)

Minister of Justice (Federal)

Minister of Justice (Federal)

Minister of Justice (Federal)

Chief Justice

Minister of Justice (Federal)

Canadian Bar Association

Provincial Law Society

Minister of Justice (Provincial)

Chief Justice

Chief Justice

Chief Justice

Provincial Law Society

Provincial Law Society

Minister of Justice (Federal)

Minister of Justice (Federal)

Minister of Justice (Federal)

Canadian Bar Association

Minister of Justice (Provincial)

Chief Justice

Minister of Justice (Federal)

Minister of Justice (Provincial)

Minister of Justice (Federal)

Provincial Law Society

Canadian Bar Association

Minister of Justice (Provincial)

Provincial Law Society

Minister of Justice (Federal)

Minister of Justice (Federal)

\section{Saskatchewan}

Axtell, Glayne

Barber, Susan

Cameron, Jean

Bazylak, Ron

Embury, Margo

Fedoruk, Sylvia

Gauley, David

Gerein, W.F.
Minister of Justice (Provincial)

Provincial Law Society

Minister of Justice (Federal)

Minister of Justice (Provincial)

Minister of Justice (Federal)

Minister of Justice (Federal)

Provincial Law Society

Chief Justice 
Gerrand, Gerald L.

Gerrand, Gerald L.

Gillis-Cipywnyk

Glazer, Christine

Jackson, G.

Johnson, F. William

Kuski, Gordon

Lafond, Carol

Linn, Dale

Maher, R. Dennis

Matheson, William

McKercher, Robert

Nasser, Karim

Paus-Jenssen, Arne

Strudwick, Donna

Talus, Calvin

Wells, Deborah

Young, Gary

\section{Yukon}

Adamson, Shirley

Austring, Lorne N.

Christensen, Ione J.

Fingland, Frank

Fingland, Frank

Florence, Malcolm

Gawn, Penelope

Gingell, Judy

Hancock, Vicki

Hudson, Ralph

King, Aletta Anne

Macdonald, R. Grant

Maddison, Harry

Neschokat, Sylvia

O'Brien, Paul

Patnode, Bruce

Preston, Timothy

Veale, Ronald S.

Wright, John
Provincial Law Society

Minister of Justice (Federal)

Minister of Justice (Federal)

Minister of Justice (Federal)

Chief Justice

Canadian Bar Association

Provincial Law Society

Minister of Justice (Provincial)

Canadian Bar Association

Canadian Bar Association

Chief Justice

Canadian Bar Association

Minister of Justice (Federal)

Minister of Justice (Federal)

Minister of Justice (Provincial)

Chief Justice

Minister of Justice (Federal)

Canadian Bar Association

Minister of Justice (Territorial)

Minister of Justice (Federal)

Minister of Justice (Federal)

Minister of Justice (Territorial)

Minister of Justice (Federal)

Territorial Law Society

Canadian Bar Association

Minister of Justice (Federal)

Minister of Justice (Federal)

Senior Judge

Canadian Bar Association

Territorial Law Society

Senior Judge

Minister of Justice (Territorial)

Territorial Law Society

Minister of Justice (Federal)

Canadian Bar Association

Territorial Law Society

Minister of Justice (Territorial) 


\section{AṔ́ENDIX 3}

\section{MINISTERS OF JUSTICE AND COMMISSIONERS FOR Federal Judicial AFFairs 1988-1999}

\section{Ministers of Justice}

Honourable Ray Hnatyshyn

Honourable Joe Clark

Honourable Doug Lewis

Honourable Kim Campbell

Honourable Pierre Blais

Honourable Allan Rock

Honourable Anne McLellan
June 1986 - December 1988

December 1988 - January 1989

January 1989 - February 1989

February 1989 - January 1993

January 1993 - November 1993

November 1993 - June 1997

June 1997 -

\section{Commissioners for Federal Judicial Affairs}

Pierre Garceau, Q.C.

Guy Y. Goulard, Q.C.
February 1982 - December 1993

August 1994 


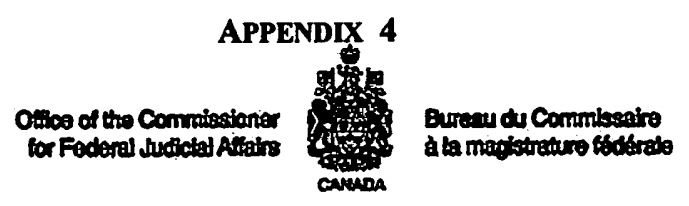

CONFIDENTIAL

FEDERAL JUDICIAL APPOINTMENTS

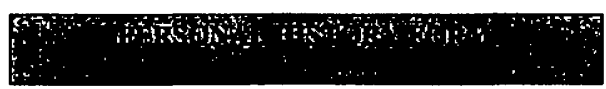

1. Complete the attached Personal History Form and authorization form.

The forms must be dated and signed. Incomplete forms will be returned.

2. Provide any additional information which you believe useful. If the space provided in the Personal History Form is not sufficient you may supplement it by attaching appropriately numbered sheets. A currriculum vitae can also be attached but not as a substitute for completing the form, which should include a full chronology of your work history. Do not write on the back of pages. While not required, letters of recommendation will also be considered by the Committee if provided. A recent photograph is optional.

3. Return the completed Personal History Form and other material to:

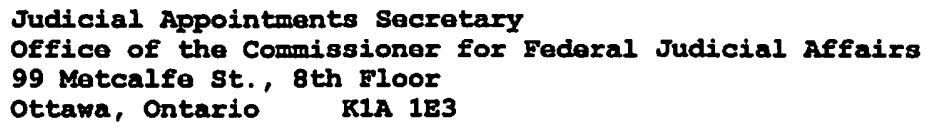

Telephone: (613) 992-9400

Fax: (613) 941-0607

This Personal History Form and other material received will be submitted to the appropriate Advisory Committee in your province or territory which will assess your candidature and report its assessment to the Minister of Justice. Each candidate will be notified of the date of his/her assessment following its completion by the Committee. Assessments are valid for a period of two years, after which time a candidate may submit a new application for another assessment.

All information will be kept in confidence. When making inquiries the Advisory Committee will make every effort to maintain confidentiality.

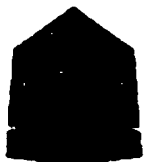

Ottrwa, Ontario K1A $1 E 3$ 


\section{CONFIDENTIAL}

\section{PERSONAL HISTORY FORM}

Surname :

Given Names:

Usual First Name:

Date of Birth: $\frac{1}{\text { (Day/Month/Year) }}$ Male $\square \quad$ Female

Business Address:

(law firm, etc.)

Use as mailing

(number, street, suite)

address $\square$

\begin{tabular}{ll}
\hline (city) & (province, postal code) \\
$\frac{(1)-}{\text { (telephone: area code \& number) }} \frac{(1)}{\text { (fax: area code \& number) }}$
\end{tabular}

Residence Address:

Use as mailing

$$
\text { (number, street, apt.) }
$$

(city), (province, postal code) address $\frac{(1)-}{(\text { telephone: area code \& number })} \frac{(1)-}{(\text { fax: area code \& number })}$ Have you previously submitted your name for consideration for a federal judicial appointment? If so, please give the date and jurisdiction (province or territory) of your prior submission.

No $\square$ Yes $\square$ Date: Jurisdiction:

Member of the Bar of

Since: $\frac{/ 1}{(D / M / Y)}$ Past or present membership in Other Bars Date of membserhip: $\frac{/ /}{(\mathrm{D} / \mathrm{M} / \mathrm{Y})}$ Primary location and Judicial Region of your practice or occupation: 


\section{CANDIDATE FOR}

Select ONE province or territory only. Except for the territories, you must be a member of the bar of the jurisdiction for which you submit the form. If you wish to be a candidate in more than one province or territory, please submit a separate and complete Personal History Form for each province or territory.

\begin{tabular}{|c|}
\hline 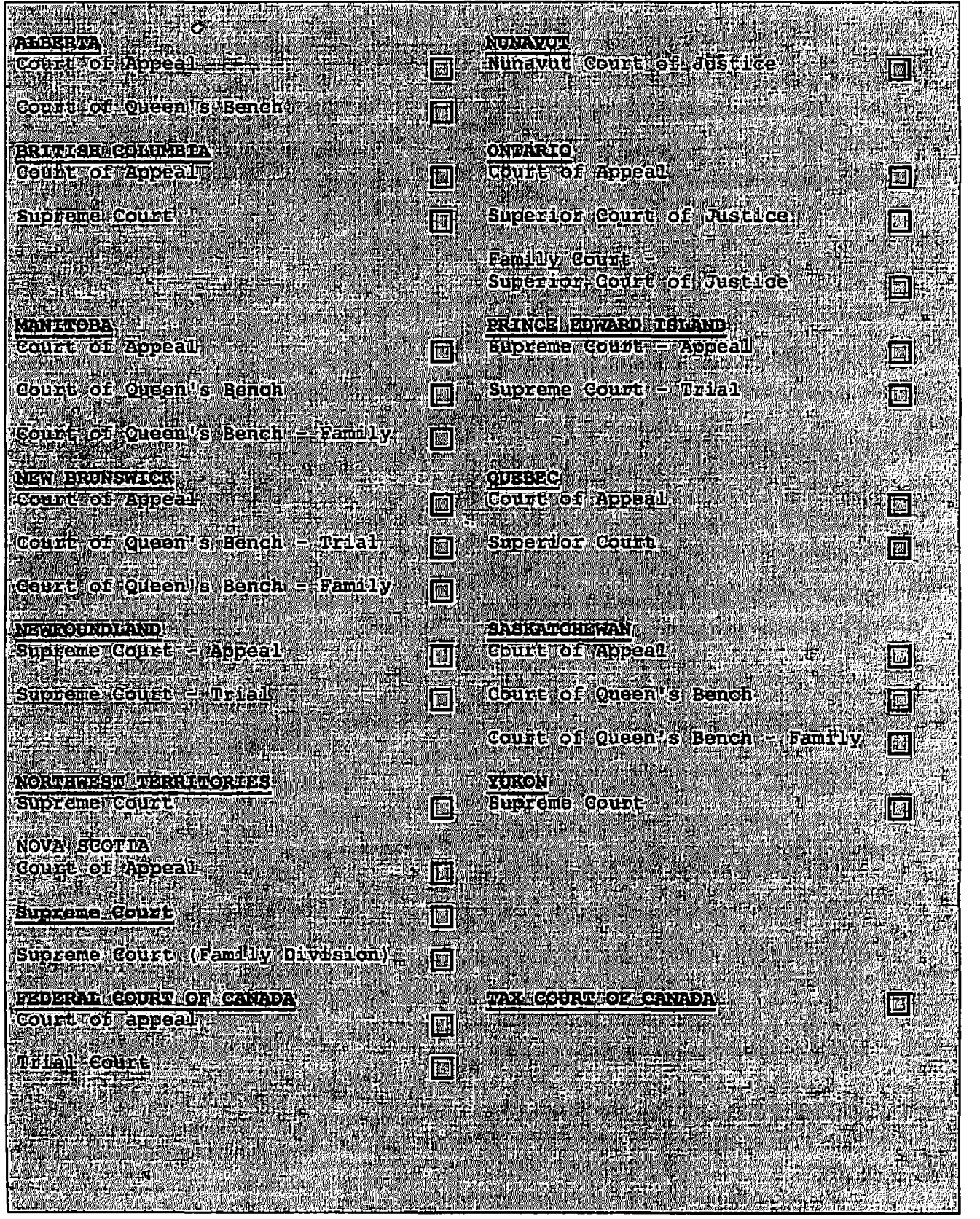 \\
\hline
\end{tabular}




\section{PLACE OF RESIDENCE}

If appointed, I would be willing to reside:

Anywhere in the province or territory

Only in (please be specific)

In the National Capital Region (required for Federal or Tax Court)

\section{TRAVEL}

If appointed, I would be willing to travel extensively within the province or territory or within Canada, as required by the court.

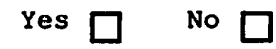

Comment:

\section{LANGUAGE(S)}

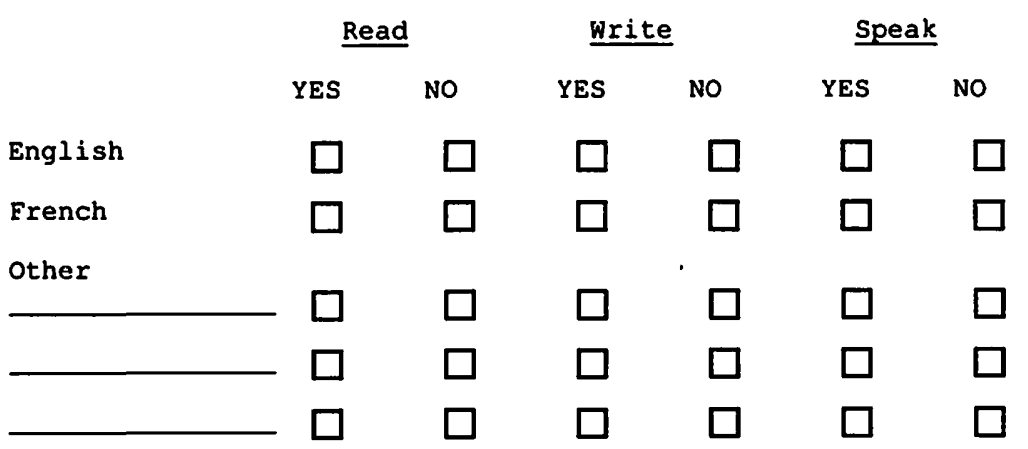

Language(s) in which you are competent to hear and conduct a trial:

English $\square \quad$ French $\square$ Other 
EDUCATION Name of institution, years attended, degree/diploma obtained.

Postgraduate:

Law School:

University:

Continuing Education:

Academic awards: 
PROFISSIONAL AND EMPLOYMINT HISTORY Please include a chronology of all work experience, starting with the most recent and showing clear time periods for each experience and all employers.

Legal Work Experience:

Non-Legal Work Experience:

Practice areas in the last 5 years: 
VOL. $38(3) 2000$

'lease provide the namos and telephone numbers of judges before whom and ipposing counsel with whom you have frequently appeared. If your practice loes not include courtroom work, please provide this same information ior colleagues with whom you have had files or worked frequently.

IOTE: These persons may be consulted by the committee.

ther professional responsibilities, involvement in professional associations, :eaching, publications, awards received, etc.: 
STATE REASONS FOR YOUR CANDIDATURE Please include the following in your comments: (1) How you see the role of a judge in society. (2) Your attributes for that role as :hey relate to the criteria for candidates (see «Appendix» to document on (Federal Judicial Appointments Process»). (3) Your strengths and weaknesses. 
PERSONAL \& OTHER MATTERS (Explain 'yes' answers using additional pages if required.)

Ever disciplined by a Law Society, or other professional association or regulatory body? Any pending disciplinary actions or investigative measures?

YES

NO

Ever convicted of a criminal or other offence by a court or tribunal for which you did not receive a pardon? Are you currently defending a charge for such an offence?

YES

NO $\square$

Are you in default of a family support obligation?

YES

NO

Are you insolvent, in financial difficulties or subject to potential financial claims against you, your partners or any business you may have? Have you ever declared bankruptcy or suffered severe financial difficulties? Are you in arrears with Revenue Canada or a similar provincial agency?

YES

No $\square$

Have you had any physical or mental health problems, including alcohol or drug problems, in the last five years?

YES

NO

Is there anything in your past or present which could reflect negatively on yourself or the judiciary, and which should be disclosed?

YES

NO 


\section{OPTIONAL}

Given the objective of a representative Bench, if applicable you may wish to indicate your status. There is no obligation to do so.

Visible Minority

Aboriginal

Disabled

Ethnicity/Cultural origin: 


\section{REFERENCES}

List a minimum of 4 references, both legal and non-legal, and provide the information requested below for each. ALL listed references must be available to be contacted directly by the committee. The Committee will contact a minimum of the first 4 references listed, and will also consult other sources.

NOTE: Indicate here whether you authorize the Committee to consult your partners or associates in addition to any listed in this form.

YES

No $\square$ N/A

1. Name: Occupation:

Address :

Business telephone:

Home telephone:

2. Name: Occupation:

Address :

Business telephone: $-$

Home telephone:

3. Name: Occupation:

Address :

Business telephone: $-$

Home telephone: Occupation:

4. Name: Address : 
5. Name:

Occupation:

Address :

Business telephone: $(1$,

Home telephone: 1,1

6. Name:

Occupation:

Address :

Business telephone: $(1$,

Home telephone: $(1, \ldots$

\section{ATTESTATION AND SIGNATURE}

I, (please print) attest to the veracity of

the information provided in this Personal History Form. 


\section{APPENDIX 4 (CONTINUED) \\ Federal Judicial Appointments Process}

\section{Introduction}

The federal judicial appointments process has been in place since 1988 It continues to be revised on the basis of ongoing operational experience. This document describes the process with revisions to date and is intended for those interested in submitting their candidacies for appointment, or in nominating others as candidates.

This policy applies to the appointment of judges of the superior courts of every province and territory, the Federal Court of Canada and the Tax Court of Canada.

\section{The Judicial Appointments Process}

\section{Expression of Interest}

Qualified lawyers and persons holding provincial or territorial judicial office who wish to be considered for appointment as a judge of one of the courts referred to above must apply to the Commissioner for Federal Judicial Affairs; the Commissioner maintains records of those interested in appointment and ensures that lawyer candidates are assessed by the appropriate provincial or territorial advisory committee. In addition to candidates themselves, members of the legal community and all other interested persons and organizations are invited to nominate persons they consider qualified for judicial office; nominees will be contacted by the Commissioner to ascertain whether they wish to be considered for a judicial appointment

Candidates and interested persons should write to:

Commissioner for Federal Judicial Affairs

99 Metcalfe Street, 8th Floor

Ottawa, Ontario

K1A 1E3

Phone (613) 992-9400

FAX (613) 941-0607

Upon receiving a candidate's expression of interest or a nomination, the Commissioner will request completion of a Personal History Form, which provides the basic data for the subsequent assessment of the candidature by the appropriate advisory committee. Candidates should ensure that this form is completed in full and in accordance with the instructions provided, and that it is up to date. All information received is treated confidentially.

The statutory qualifications for appointment are 10 years at the bar of a province or territory, or a combination of 10 years at the bar and in the subsequent exercise of powers and duties of a judicial nature on a full time basis in a position held pursuant to a law of Canada or of a province or territory. Candidates are asked to sign a form 
authorizing the Commissioner to obtain a statement of their current and past standing with the appropriate law society.

Upon determining that a candidate meets the threshold constitutional and statutory criteria for a federal judicial appointment, the Commissioner will forward a lawyer candidate's file to the appropriate committee for assessment.

Provincial or territorial court judges who wish to be candidates must also notify the Commissioner in writing of their interest in a federal judicial appointment and complete a Personal History Form. These candidates are not assessed by the committees, but their files are submitted to the appropriate committee for comments which are then provided to the Minister of Justice, including the results of any confidential consultations undertaken by the committee. These comments are confidential and provided to the Minister only; they are not binding on the Minister, and the names of these candidates are placed on the list of those available for appointment. Provincial and territorial court judges who apply for a federal appointment are also the subject of consultations by the Minister of Justice with their current and proposed Chief Judge and Chief Justice, and with the Attorney General or Minister of Justice of the jurisdiction concerned.

Federally appointed judges being considered for elevation to higher judicial office are the subject of consultations by the Minister of Justice. However, they do not submit a Personal History Form nor are their names submitted to the committees.

\section{Committees}

Independent advisory committees for assessing each lawyer applicant's qualifications for the bench constitute the heart of the appointments system. An advisory committee is established in each province and territory; Ontario has three regionally based committees and Quebec has two. Each committee consists of the following seven members of the bench, the bar and the general public:

- a nominee of the provincial or territorial law society;

- a nominee of the provincial or territorial branch of the Canadian Bar Association;

- a judge nominated by the Chief Justice of the province or territory;

- a nominee of the provincial Attorney General or territorial Minister of Justice; and

- three nominees of the federal Minister of Justice.

Each nominator is asked by the federal Minister of Justice to submit a list of names from whom an appointment to the relevant committee can be made. The Minister, with the assistance of the Commissioner for Federal Judicial Affairs, then selects persons to serve on each committee who reflect factors appropriate to the jurisdiction, including geography, gender, language and multiculturalism. Committee members are appointed by the Minister of Justice to serve three year terms, with the possibility of a single renewal. Lawyer members of the committees cannot themselves be candidates for judicial appointment for one year following the end of their term of office on the committee. 
Two of the federal nominees on the committee are persons, other than a practising lawyer, capable of representing the public interest. The provincial attorneys general and ministers of justice are encouraged to choose their own nominees on a similar basis.

Familiarization and information sessions are provided to new committee members, As well, the Minister of Justice meets each year with the Chairs of all committees, for an exchange of views concerning the operations of the process.

Regionally based committees have been established in Ontario and Quebec because of those provinces' large populations. Candidates are assessed by the regional committee established for the judicial district of their practice or occupation, or by the committee judged most appropriate by the Commissioner.

All committee proceedings and consultations take place on a confidential basis. Guidelines concerning confidentiality and other committee procedures are provided to each committee member. Extensive consultations in both the legal and non legal community are undertaken by the committee in respect of each lawyer applicant.

\section{Assessments}

Lawyer candidates only are assessed by the committees.

Professional competence and overall merit are the primary qualifications for appointment to the bench. Committee members are provided with criteria for evaluating fitness for the bench; these relate to professional competence and experience, personal characteristics, social awareness and potential impediments to appointment. A list of these criteria is attached as an Appendix. Committees are encouraged to respect diversity and to give due consideration to all legal experience, including that outside a mainstream legal practice. Broad consultations by the committees and community involvement through these consultations are essential elements of the process.

Committees are strongly encouraged to interview candidates whenever division within a committee or another issue preventing the completion of an assessment arises.

The committees are asked to assess candidates on the basis of three categories "recommended", "highly recommended" or "unable to recommend" for appointment. These categories reflect the advisory nature of the committee process. Ultimately responsibility and accountability for appointments rest with the Minister of Justice.

Following an assessment, the Minister may seek further information from the committee on any candidate. On those occasions when a committee's advice may be contrary to the information received from other sources by the Minister, the Minister may ask the committee concerned for a reassessment. 


\section{Confidentiality and Duration of Assessment}

Candidates are notified of the date they were assessed by the committee. They are not provided with the results of the assessment, which are confidential and solely for the Minister's use.

Assessments are valid for a period of 2 years. A new Personal History Form must be submitted during the 3 months preceding the assessment expiry date if a candidate continues to be interested in being considered for a judicial appointment after the expiry date. In that case a new assessment is undertaken, and a prior "recommended" or "highly recommend" assessment remains valid until the new assessment is completed. A new Personal History Form can also be submitted after the expiry date, but in that case a previous positive assessment will cease to be valid as of the expiry date.

Candidates who are provincial or territorial court judges need not renew their candidature after 2 years. These candidatures continue to be valid unless withdrawn by the candidate. These candidates, however, are invited to update the information submitted whenever appropriate.

\section{Commissioner for Federal Judicial Affairs and Judicial Appointments Secretary}

The Commissioner for Federal Judicial Affairs has overall responsibility for the administration of the appointments process on behalf of the Minister of Justice. The Commissioner is expected to carry out his responsibilities in such a way as to ensure that the system treats all candidates for judicial office fairly and equally. The Commissioner's responsibility is exercised directly or by his delegate, the Judicial Appointments Secretary. The Commissioner or the Appointments Secretary (or an authorized representative) normally attends every committee meeting as an ex officio member, and serves as the link between the Minister and the committees. All communications between the Minister and the committees are effected through the Commissioner or the Appointments Secretary. They assist the committee chair with the agenda regarding the assessments to be completed at each meeting, with the information required for each assessment and with all services required by the committee. It is the Commissioner's or the Appointments Secretary's particular responsibility, on behalf of the Minister, to ensure that all assessments are completed expeditiously and thoroughly. Each candidate's assessment must be certified by the Commissioner or the Appointments Secretary prior to submission to the Minister of Justice.

The files of all candidates are maintained in a separate and confidential data bank for the sole use of the Minister of Justice.

\section{Appointments}

Federal judicial appointments are made by the Governor General acting on the advice of the federal Cabinet. A recommendation is made to Cabinet by the Minister of Justice with respect to the appointment of puisne judges, and by the Prime Minister with respect to the appointment of chief justices. 
Before recommending an appointment to Cabinet, the Minister consults with senior members of the judiciary and the bar, and with the appropriate provincial or territorial attorneys general or minister of justice. The Minister welcomes the advice of interested groups and informed individuals on particular appointments, especially in the furtherance of the government's commitment to gender equality and to representativeness on the bench. The work of the committees, the informal contacts with interested groups, and the traditional consultations with senior members of the judiciary and bar and with attorneys general provide the Minister of Justice and, through the Minister, the government, with the best advice available on the qualifications, competence and overall suitability of candidates for judicial office.

\section{Conclusion}

Those considering applying for a judicial appointment should be aware of the implications of becoming a judge, and should be willing to assume the responsibilities of judicial office only if they are fully prepared to accept the significant changes it will bring, not just to their own lives, but to those of their families. As well, while training programs are provided to new judges, and continuing education is available, judges are by and large on their own.

In addition to these considerations, there are others.

The independence of the judiciary both isolates the individual judge from former associations to avoid the possibility of conflict of interest, and imposes upon a judge the highest standards in performing the duties and responsibilities of judicial office. It requires that each judge devote himself or herself exclusively to the duties of the judicial office, and not engage in any outside business. The range of activities that are available to a practising lawyer is severely curtailed upon appointment to the bench.

At the same time, a reasonably long-term commitment is required from each judge: generally, judges cannot retire with a pension, except on medical grounds, until they have served 15 years in office and the total of their age and years in office equals at least 80. Appointees must remain on the bench until the statutory requirements for retirement with a pension are met, or leave with only a return of contributions. Mandatory retirement is at age 75 .

All who aspire to judicial office should be aware that their responsibilities will include not only the fair and just application or the law but the maintenance of the high reputation of the judiciary itself. Candidates should be prepared to make full disclosure of any matter that would reflect upon their ability to perform the functions of judicial office, or upon the credibility and repute of the judiciary as a whole.

Once appointed, judges are expected to comport themselves so that no criticism attaches to their office. The judge is not permitted to engage in public debate on any of his or her decisions, and should avoid expressing personal opinions on major social issues which might lead to an apprehension of bias when such issues come to be adjudicated by the courts. When a judge performs his or her duties in a way that falls short of the 
standards expected of the bench, or where the personal life of the judge intrudes upon his or her judicial duties, a complaint may be made to the Canadian Judicial Council. The Council has a statutory mandate to investigate all complaints and allegations of misconduct on the part of federally appointed judges and to recommend to the Minister of Justice whether there are grounds for removing a judge from office.

Persons who require additional information concerning the federal judicial appointments process should contact the Commissioner for Federal Judicial Affairs or the Judicial Appointments Secretary at 99 Metcalfe Street, 8th Floor, Ottawa, Ontario, K1A 1E3. Tel. (613) 992-9400; FAX (613) 941-0607. Inquiries specifically related to matters such as judicial allowances and benefits, remuneration, taxation, discipline, training and professional development should be addressed to the Deputy Commissioner for Federal Judicial Affairs at the same address or at tel. (613) 995-7438. 


\section{APPENDIX 5}

\section{CANDidates fOR Federal Judicial APPOINTMENT}

\section{Criteria}

\section{Professional Competence and Experience}

- proficiency in the law

- well rounded legal experience

- advocacy experience

- commitment to the law

- ability to exercise role conferred by Charter

- standards / reputation

- mature \& objective judgement

- work habits

- writing \& communication skills
- organizational skills incl. people and time management

- collegiality

- scholarly ability

- achievements \& contributions incl. books and articles

- areas of specialization

- non-mainstream legal experience

- bilingualism

\section{Personal Characteristics}

- ethical standards

- honesty

- integrity

- fairness

- tolerance

- patience
- common sense

- ability to listen

- ability to make decisions

- consideration for others
- courtesy

- tact

- humility

- reliability

- punctuality

\section{Social Awareness}

- sensitivity to gender and racial equality

- appreciation of social issues arising in litigation
- public and community service

- receptivity to ideas

\section{Potential Impediments to Appointment}

- drug or alcohol dependency

- civil or criminal actions

- health

- sexual harassment complaints
- professional complaints and/or disciplinary actions

- financial difficulties

- default of family support obligations 